\title{
The Impact of Conversion from Traditional to Electronic Dealing on Trade Volume and Market Value of Stocks:An Applied Study on Amman Bourse
}

\author{
Matar khaleel dr.Mousa Saeed \\ Instructor Of Finance And Banking Department, Al-Ballquqa Applied University \\ Dr.mousa Abdelhadi Salah Noafal \\ Instructor Of Accounting Department, Al-Ballquqa Applied University
}

\begin{abstract}
This study aims to test the effect of conversion from traditional trading to electronic trading on trade volume, stock market value and liquidity in Amman Bourse, and investigating the impact of the electronic trading on either transaction costs and operational efficiency, it is also aims to investigate the ability of investors to earn abnormal return by converting from manual to electronic trading This study will use secondary data by gathering stock market prices before and after dealing with electronic trading. The behavior of stock market value and trade volume are studied on the basis of daily movements. On this paper an attempt was made to analyze the stock market value and trading volume of all shareholding companies listed in Amman bourse using monthly data because it is more stable and less volatile. The hypothesizes of this study were examined by using parametric tests like paired sample t.test. it was found that there was an increase in either trading volume of stocks, stock market value ,liquidity, operational efficiency, and decreasing in transaction costs . This study can be a source of help to institutional investors and market makers to improve either way of building their portfolios and to diversify it and improve their investment decisions.
\end{abstract}

Keywords: trade volume, electronic trading, manual trading, abnormal return, operational efficiency.

DOI: $10.7176 /$ RJFA/10-18-08

Publication date:September $30^{\text {th }} 2019$

\subsection{Introduction}

Financial markets is considered as a key instrument for information used to make financial decisions by financial institution, creditors and investors because it has multi information content for these groups .

Trading volume provide key information for current and antispted investors, creditors and many other groups to make rational decisions related to their investment, loans and portfolios .

Electronic trading in Amman Bourse was started in year 2000, before that year, manual trading was implemented .minimizing transaction costs and increasing operational efficiency were the goals of Amman Bourse to convert from manual to electronic trading.

\subsection{Importance of the study}

Amman Bourse is one of of the emerging markets in middle east ;in order to compete with other capital markets in the region ,conversion to electronic trading wasn't a choice but it's a mandatory decision to keep up with technology to increase either liquidity and efficiency in the market .in addition, this will lead to a deep market, which will attract more investors either citizens or foreigners .

\subsection{Objective of the study}

The main objectives of the study

1- to examine the impact of conversion to electronic trading- in Amman Bourse- on trading volumes.

2- to examine the impact of conversion to electronic trading on market stock prices.

-to examine the impact of conversion to electronic trading on liquidity. 3

4--to examine the impact of conversion to electronic trading on transaction costs and operational efficiency.

\subsection{Problem statement}

this study is intended to examine the following three major hypothesis:

1.It is expected that conversion to electronic trading in Amman Bourse will lead to increase in trade volumes.

2.It is expected that conversion to electronic trading in Amman Bourse will lead to increase in stock market value.

3. .It is expected that conversion to electronic trading in Amman Bourse will lead to increase in liquidity

4 .It is expected that conversion to electronic trading in Amman Bourse will lead to increase in operational efficiency. 


\section{5 literature review}

According to (Quadoomi,2006) many advantages had been accomplished from conversion from manual to electronic trading; either trade volume and operational efficiency had been increased .

Peter and Edie(2004) had reached to more survival to firms and financial intermediaries which can adapt with new technology in Australia market.

Nir Vulkan(2003) compared traditional and electronic trading in London market ,and concluded that electronic trading had increased trade volume especially in bonds.

Heman(2002) have studied the risk from adopting technology in NYSE and London market and concluded that more utilizing technology had increased manipulation and risk.

\subsection{Methodology}

To achieve the main objectives of the study, the data for this study was gathered from secondary sources -the closing prices of stocks and trade volumes as published in Amman bourse (1995-2005) markets .

Year 2000(which is the year that electronic trading was adopted) was considered a base year ,then the average mean of trade volume and market stock value is calculated before and after that year,

parametric tests like paired sample t.test had been used to investigate the the study hypothesizes;

the return of market portfolio which was measured by the percentage change of Amman Bourse financial indicator had been estimated during the two sub intervals to investigate the impact of electronic trading on market value of stocks.

\subsection{Results and Analysis}

1.testing the first hypothesis: it is expected that conversion from manual to electronic trading will increase the trade volume ;

Table (1-1) paired sample test

\begin{tabular}{|l|l|l|l|l|}
\hline Mean residual & t-calculated & t-tabulated & Sig. & Result of hypothesis \\
\hline 23543 & 6.6755 & 1,91818 & 0.023 & accept \\
\hline
\end{tabular}

This study was examined using paired sample t.test ,using sig. of $5 \%$, it is found that there is a statically difference between trade volume before and after conversion from manual to electronic trading .

2.testing the second hypothesis: it is expected that conversion from manual to electronic trading will increase stock market value

Table (1-2) paired sample t.test

\begin{tabular}{|l|l|l|l|l|}
\hline Mean residual & T calculate & tabulated & Sig. & Result \\
\hline 6265 & 2.435 & 1.9818 & 0.032 & Accept \\
\hline
\end{tabular}

This hypothesis was examined using paired sample test, it is found that there is a statically difference between market stock value before and after the conversion from manual to electronic trade .

3.testing the third hypothesis :

1.testing the first hypothesis: it is expected that conversion from manual to electronic trading will increase the liquidity .

Table (1-3) paired sample t.test

\begin{tabular}{|l|l|l|l|l|}
\hline Mean residual & T calculate & tabulated & Sig. & Result \\
\hline 3298 & 4.876 & 1.9818 & 0.022 & Accept \\
\hline
\end{tabular}

This hypothesis was examined using paired sample test, it is found that there is a statically difference between liquidity before and after the conversion from manual to electronic trade .

4.testing the fourth hypothesis:

it is expected that conversion from manual to electronic trading will decrease transaction costs and increase increase operational efficiency.

Table (1-4) paired sample t.test

\begin{tabular}{|l|l|l|l|l|}
\hline Mean residual & T calculate & tabulated & Sig. & Result \\
\hline 3298 & 4.876 & 1.9818 & 0.022 & Accept \\
\hline
\end{tabular}

Results:

After analyzing the data and testing the hypothesis the following results were extracted:

1.it has been found that conversion from traditional trading to electronic trading had increased the trading volume of stocks.

2. 1.it has been found that conversion from traditional trading to electronic trading had increased the market value of stocks1

3.it has been found that conversion from traditional trading to electronic trading had increased the liquidity in the market.

4. 1.it has been found that conversion from traditional trading to electronic trading had decreased the transaction 
costs and increase operational efficiency.

\subsection{References}

1.Quadomi,2006,the impact if conversion to electronic dealing on operational efficiency in Amman stock exchange,Albalqua for research ,vol.11,no.2,2006.

2.Gharavi,Hussein,2004,Informationand technology in the banking industry,MCB university press,vol.104,no.9

3.Fairchild,A.M and Fibbers ,2004,A success factor for electronic markets ,Business process management journal,vol.10,no.1.

4.Vulkan,Nair,2003,Electronicdealing win over traditional trading, economic research council,www.science.com. 5.Kippen,Berger,1999,big bang-again ,antidote journal,vol.4,no.5. 